\title{
SEGMENTED DOUBLE-STRANDED GENOMIC RNA VIRUSES IN FECAL SAMPLES FROM BROILER CHICKEN
}

\author{
Claudia Yurika Tamehiro; Alice Fernandes Alfieri; Kerley Cristina Médici; Amauri Alcindo Alfieri* \\ Laboratório de Virologia Animal, Departamento de Medicina Veterinária Preventiva, Centro de Ciências Agrárias, \\ Universidade Estadual de Londrina, Londrina, PR, Brasil.
}

Submitted: August 26, 2002; Returned to Authors for corrections: April 04, 2003; Approved: November 03, 2003

\begin{abstract}
Segmented double-stranded RNA (dsRNA) viruses were identified by polyacrylamide gel electrophoresis (PAGE) technique in fecal samples from broiler chicken. A total of 378 fecal samples from 1-7 weeks old chickens were analyzed. dsRNA with migration profile characteristic of avian rotavirus (AvRV), reovirus (ARV) or picobirnavirus (PBV) was identified in 32 (8.5\%), 7 (1.8\%) and $13(3.4 \%)$ samples, respectively. AvRV and ARV occurred more frequently in chickens up to 1 month old and were related with enteritis signs. Considering only fecal samples of chickens with diarrhea, the AvRV was detected in $37.8 \%$ (14/37) and the ARV in $13.5 \%$ (5/37) of analyzed samples. AvRV was identified in only $1.5 \%(4 / 274)$ and ARV was not detected in normal feces collected from assymptomatic chickens (controls). PBV dsRNA was detected in broiler chickens from two to seven weeks old, more frequently in feces with pasty consistency. The AvRV showed great electrophoretic profile variability in the dsRNA segments and nine different electropherotypes were identified. Variation in genome pattern was not observed in either ARV or PBV.
\end{abstract}

Key words: Avian rotavirus, avian reovirus, avian picobirnavirus, broiler chickens, diarrhea, PAGE.

\section{INTRODUCTION}

The enteric disturbances, which occur mainly in the first weeks of life in many mammalian and avian species, are frequently of viral etiology. Different viruses, such as rotavirus, reovirus, adenovirus, enterovirus, coronavirus, herpesvirus, parvovirus, astrovirus, calicivirus and picobirnavirus $(1,5,8,19)$ can be isolated from the intestinal content of birds with enteritis and/or clinically healthy birds.

Viruses from the genera Orthoreovirus and Rotavirus of the family Reoviridae, are the most frequently identified viruses in broiler chicken feces at four weeks of age. Avian rotavirus (AvRV) and avian reovirus (ARV) are common viral agents that cause enteritis of variable severity in poultry, especially during the early stages of life. These viruses are almost always associated with clinical signs of enteritis, dehydration, depression and anorexia. In this condition the flocks increased feed conversion rate, depressing growth rate, decrease flock uniformity, increasing susceptibility to other diseases, medications costs and mortality rate $(5,8,13,18)$. AvRV and ARV have already been identified in broiler chicken feces in Brazil by Alfieri et al. $(2,3)$.

Various methods have been developed for the diagnosis of infection caused by AvRV and ARV, including virus isolation in primary or continuous cells line, direct or immune electron microscopy. These methods are not used for rotine diagnosis because all of than are time consuming and expensive. Immunological methods, like ELISA and latex-agglutination are not in commun use because of the unavailability of specific reagents $(17,25)$.

The genome consisting of segmented double-stranded (ds) RNA of the AvRV (11 segments) and ARV (10 segments) can be analyzed using silver-stained polyacrylamide gel electrophoresis (PAGE). The use of PAGE for detection AvRV and ARV in feces has the advantages of simplicity, economy, and faster, and which simultaneously identifies the migration profile of the genomic

*Corresponding author: Mailing Address. Departamento de Medicina Veterinária Preventiva, Centro de Ciências Agrárias, Universidade Estadual de Londrina, Campus Universitário. Caixa Postal 6001. 86051-990, Londrina, PR, Brasil. E-mail: alfieri@uel.br 
segments or electropherotype. This methodology, which is used in human and animal rotavirus diagnosis, is easy to use and allows identification of other segmented dsRNA virus such as picobirnavirus $(1,2,3,10,26)$.

The PAGE technique was used in this study to identify viruses with dsRNA genomes from normal and diarrheic fecal samples from broiler chickens. Some epidemiologic aspects of the identified viruses were also studied.

\section{MATERIALS AND METHODS}

\section{Fecal samples}

From January 1997 to February 1999 fecal samples of 378 broiler chickens, with one to seven weeks old, were collected from poultry farms located in the Northern, Western and Southwestern regions of Paraná State, Brazil. The samples from poults up to one week old, and from those with intense diarrhea, were a pool of intestinal contents of five poults by sample. In the other age groups each fecal sample, also in a pool form, was collected directly from the bedding (rice hulls) at nine distinct points in the aviary and each sample represented the broiler chicken population of the flock. All the samples were classified on collection according to their consistency, as diarrheic feces (liquid or semi-liquid feces), pasty or normal. The flocks with enteric disease were further characterized by clinical signs such as diarrheic feces, dehydration, dirty cloaca, ununiformity of the lot and findings of necropsy, especially enteritis. The samples were immediately taken to the laboratory and stored at $-20^{\circ} \mathrm{C}$ if not tested immediately.

\section{Nucleic acid extraction}

The nucleic acid extraction, both in the fecal samples and in virus reference strains produced in cell culture (positive control), was carried out by an association of phenol/chloroform/isoamyl alcohol (25:24:1) and the silica/guanidine isothiocyanate (GnTCN) techniques described by Theil et al., and Boom et al., respectively $(24,6)$. The extracted dsRNA was stored at $-20^{\circ} \mathrm{C}$ until use in PAGE.

\section{PAGE}

The presence of the viruses with segmented dsRNA genomes was analyzed by PAGE technique followed by silver staining. Electrophoresis in polyacrylamide gel at $7.5 \%$ with discontinuous $\mathrm{pH}$ system was used to separate the dsRNA segments, according to Laemmli (16) and Pereira et al. (22) except that the SDS was omitted from the concentration and resolution gels and from the run buffer. After the electrophoretic run, using constant voltage (100 volts), the gel was stained with silver nitrate according to Herring et al. (15).

\section{Cell and virus}

The MA104 cells, grow in Eagle's MEM supplemented with $10 \%$ fetal bovine serum, tryptose phosphate broth and antibiotics, were used for propagate rotavirus strains in presence of trypsin, as described earlier (11). NCDV (Nebraska Calf Diarrhea Virus) prototype strain of group A bovine rotavirus and OSU (Ohio State University) of group A porcine rotavirus were used as positive control of dsRNA in PAGE technique

\section{Statistical analysis}

The results were analyzed by the chi square test (12).

\section{RESULTS AND DISCUSSION}

The PAGE technique showed dsRNA presence in $13.7 \%$ (52/378) of the fecal samples. The genomic segment migration profile analysis of the 52 positive samples enabled the identification of electropherotype characteristics of AvRV, ARV and PBV in $32(8.5 \%), 7(1.8 \%)$ and $13(3.4 \%)$, samples respectively.

In 10 AvRV positives fecal samples the polyacrylamide gel show electroforetic profile with unidentified contaminating bands with molecular mass and equimolar concentration different than AvRV. Since these samples were collected in a pool form from five poults or in nine distint place in the aviary, this result may to indicate simultaneous infections by AvRV and ARV or PVB, or then infection by AvRV with different electropherotype in the same poultry flocks. Fig. 1 shows some electropherotypes of dsRNA viruses identified by PAGE in this study.

AvRV infections were more frequent in broiler chickens up to one month old and represented $87.5 \%$ (28/32) of the diagnosis of this virus. A significant increase $(\mathrm{P}<0.05)$ in the rate of AvRV identification in two week old poults was observed within this

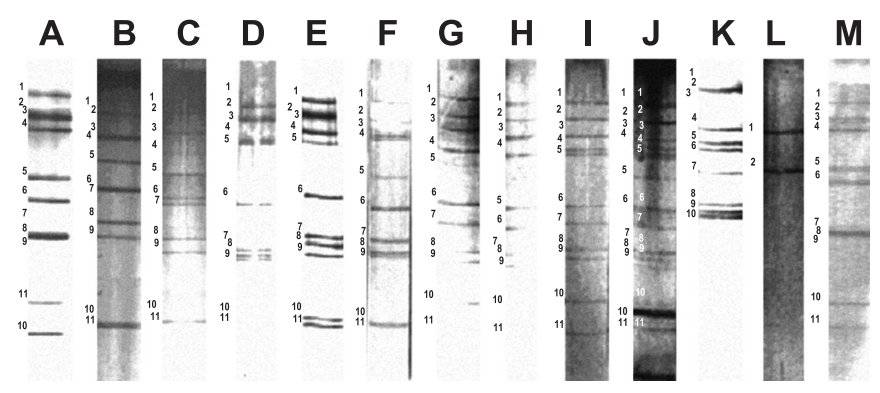

Figure 1. Rotavirus, reovirus and picobirnavirus electropherotypes identified in broiler chicken feces by silverstained polyacrylamide gel electrophoresis.

Lines A and M: Genome pattern of group A bovine (NCDV strain) and porcine (OSU strain) rotavirus, respectively; Lines B to J: Avian rotavirus with differents electropherotypes. Obs. Lines F, G and J present unidentified contaminating bands with distinct equimolar concentrations; Line K: Avian reovirus electropherotype; Line L: Avian picobirnavirus electropherotype Genome segments of viruses are numbered 1-11. 
age group where $20.4 \%$ (10/49) of the samples were positive in PAGE (Table 1).

In a longitudinal analysis carried out in young poultry flocks, McNulty et al. (20) described that, because of probable modulation of the passive immunity of maternal origin, the AvRV is not normally excreted in poultry feces of chickens less than 14 days old. However, $43.7 \%$ (14/32) of the AvRV diagnoses in the present study were made on one or two week old poults. Several factors may have influenced the susceptibility of the young chickens to rotavirus, such as passive immunity level, infecting dose, strain virulence, simultaneous infection with different AvRV serotypes or even with others enteropathogens, management failures and stress (21).

The frequency of AvRV diagnosis in poultry older than four weeks was $12.5 \%(4 / 32)$ of the positive samples. This result shows the greater resistance of this age group to infection, probably resulting from the establishment of immunocompetence by the broiler chicken (28).

$28(87.5 \%)$ of the 32 samples positive for AvRV come from chickens with clinical enteritis signs and diarrhea. AvRV was identified in $37.8 \%$ (14/37) and in 20.9\% (14/67) of the diarrheic

Table 1. Frequency of rotavirus (AvRV) reovirus (ARV) and picobirnavirus (PBV) detected by polyacrylamide gel electrophoresis (PAGE) in broiler chicken feces samples, distributed according to age, Londrina, PR, Brazil, 1997-1999.

\begin{tabular}{ccrrrr}
\hline AGE / & Total & \multicolumn{4}{c}{ PAGE Result } \\
\cline { 3 - 6 } WEEK & Samples & AvRV & \multicolumn{1}{c}{ ARV } & \multicolumn{1}{c}{ PBV } & Negative \\
\hline $1^{\text {st }}$ & 44 & $4(9.1)$ & $3(6.8)$ & - & $37(84.1)$ \\
$2^{\text {nd }}$ & 49 & $10(20.4)$ & & - & $39(79.6)$ \\
$3^{\text {rd }}$ & 66 & $7(10.6)$ & $3(4.6)$ & $2(3.0)$ & $54(81.8)$ \\
$4^{\text {th }}$ & 80 & $7(8.7)$ & $1(1.3)$ & $2(2.5)$ & $70(87.5)$ \\
$5^{\text {th }}$ & 83 & $3(3.6)$ & - & $1(1.2)$ & $79(95.2)$ \\
$6^{\text {th }}$ & 30 & $1(3.3)$ & - & $5(16.7)$ & $24(80.0)$ \\
$7^{\text {th }}$ & 26 & - & - & $3(11.5)$ & $23(88.5)$ \\
\hline Total & 378 & $32(8.5)$ & $7(1.8)$ & $13(3.4)$ & $326(86.2)$ \\
\hline
\end{tabular}

Table 2. Frequency of rotavirus (AvRV) reovirus (ARV) and picobirnavirus (PBV) detected by polyacrylamide gel electrophoresis in broiler chicken feces samples, distributed according to feces consistency, Londrina, PR, Brazil, 1997-1999.

\begin{tabular}{cccccc}
\hline Feces & Total & \multicolumn{4}{c}{ PAGE Result } \\
\cline { 3 - 6 } Consistency & Samples & AvRV & \multicolumn{1}{c}{ ARV } & PBV & Negative \\
\hline Diarrheic & 37 & $14(37.8)$ & $5(13.5)$ & - & $18(48.6)$ \\
Pasty & 67 & $14(20.9)$ & $2(3.0)$ & $7(10.4)$ & $44(65.7)$ \\
Normal & 274 & $4(4.1)$ & - & $6(2.2)$ & $264(96.3)$ \\
\hline Total & 378 & $32(8.5)$ & $7(1.8)$ & $13(3.4)$ & $326(86.2)$ \\
\hline
\end{tabular}

and pasty feces samples, showing a positive correlation $(\mathrm{P}>0.05)$ among its diagnosis and alterations in the feces consistency (Table 2). A similar result was reported by Decaesstecker et al. (8) in Belgium that using electron microscopy technique showed a positive frequency of $25 \%$ for AvRV in 102 diarrheic fecal samples from broiler chicken up to a month old.

The importance of the AvRV in the enteric process in broiler chickens was further ratified by the results obtained in normal feces samples included as controls. This sampling, obtained from clinically healthy birds, represented $72.5 \%$ (274/378) of the total analyzed but only 1.5\% (4/274) was positive for AvRV (Table 2). These results show that in the period and region studied AvRV was an important etiological agent of enteric disturbances, especially in broiler chickens up to a month old.

The enteric ARV, even though the virus was identified at a lower frequency, was also important in the diarrhea etiology which occurred in broiler chickens up to one month old (Table 2). Of the 37 diarrheic samples analyzed the ARV dsRNA was detected in $5(13.5 \%)$ samples which further represent $71.4 \%$ (5/ 7) of the ARV diagnosis made in the assessed sample. The low ARV frequency in pasty feces (3.0\%) and its non-detection in normal feces suggest that its presence in broiler chickens feces is related to the alteration in the feces consistency, characterizing a probable enteric disturbance (Table 2).

PBV has already been described in the intestinal contents of several mammal species and also in poultry $(1,4,7,23)$. The genome is composed by two $(2.6 \mathrm{a} 1.9 \mathrm{Kbp})$ or three $(2.9 ; 2.4 ; 0.9$ $\mathrm{Kbp}$ ) segments of dsRNA (27). However, its presence has not been correlated with clinical diarrhea situations, except in humans infected by the human immunodeficiency virus (HIV) and with clinical AIDS signs (14). 13 (3.4\%) of the 378 feces samples analyzed by PAGE in this study had two dsRNA segments with molecular mass, and consequently migration profile, compatible with PBV. This virus was identified in broiler chicken feces from 2 to 7 weeks old. However, they were more frequent in $6(13.3 \%)$ and $7(11.5 \%)$ weeks old chickens compared with that observed in one to four weeks old poults (Table 1). The correlation of PBV diagnosis in feces with alterated consistency (diarrheic and pasty) collected from broiler chickens with clinical signs of the enteritis was significant $(\mathrm{P}<0.05)$ when compared with normal (control) feces (Table 2).

The rates of detection of the three viruses (AvRV, ARV and PBV) in normal consistency feces, from chickens in the susceptible age groups, were low and represented 1.5\%,0\% and $1.8 \%$ for AvRV, ARV and PBV, respectively. The diagnosis frequency of these viruses increases considerably when only the pasty and diarrheic feces are considered.

The use of the PAGE technique, besides diagnostic, also enabled analysis of some molecular aspects of the three viruses present in the assessed fecal extracts. No significant alterations in the migration profiles in PAGE of the ARV and PBV dsRNA genomic segments were observed. Only one electropherotype 
of each virus was identified. This result suggests a probable genome stability, both in the ARV and the PBV, present in broiler chicken feces in the period and regions studied.

Human and animal (mammals) RV vary greatly in their electrophoretic profile (9). AvRV with the atypical RNA profile, characterized mainly by changes in the segregation characteristics of dsRNA segments 7, 8 and 9 were very frequent $(21,26)$. Similarly, in this study AvRV with nine distinct electropherotypes was identified. Only three strain had a similar profile to the group A of AvRV, characterized by greater molecular mass of the fifth genomic segment and by the co-migration of the segments 10 and 11 .

The electrophoretic variability of AvRV observed in this study indicates the molecular complexity of this virus in broiler chickens. Even though there is no direct correlation between electropherotype and serotype, significant variations in eletrophoretic mobility of dsRNA segments can give rise to viral particles with antigenic variation in protein which induces neutralizing antibodies $(21,26)$.

The results of this study show that in the assessed broiler chickens flocks, both ARV and mainly AvRV were directly related to diarrhea observed in broiler chickens up to a month old. Depending on the degree of damage to the flocks, this virus may cause significant reduction in the weight gain and food conversion rates of the flocks, as well as a significant increase in the death rate, with a consequent fall in profit. The variations in the genome profiles found in the AvRV samples suggest the presence of antigenically distinct samples, which may further hamper diagnosis, control and prophylaxis of the avian rotavirus. Complementary studies on the avian picobirnavirus epidemiology should be carried out to characterize the real importance of this virus in broiler chickens enteric infections.

\section{ACKNOWLEDGEMENTS}

The authors wish to thank the financial support provided by the following Brazilian Institutions: CAPES, CNPq, and CPG/ UEL. Alfieri, A.A. is recipient of CNPq fellowship.

\section{RESUMO}

\section{Vírus com genoma RNA fita-dupla segmentado em fezes de frangos de corte}

A técnica de eletroforese em gel de poliacrilamida foi utilizada com o objetivo de identificar vírus com genoma contituído por RNA de fita dupla (dsRNA) segmentado, em material fecal de frangos de corte. Foram analisadas 378 amostras de fezes de aves, com idade entre a primeira e sétima semanas de vida, provenientes de granjas avícolas localizadas no Estado do Paraná, Brasil. dsRNA com perfil de migração característico de rotavírus (AvRV), reovírus (ARV) ou picobirnavírus (PBV), foi identificado em $32(8,5 \%), 7(1,8 \%)$ e $13(3,4 \%)$ amostras, respectivamente. AvRV e ARV ocorreram com maior frequiência em aves com até um mês de idade e estiveram diretamente relacionados a fezes diarréicas e pastosas, provenientes de aves com sinais clínicos de enterite. Considerando-se apenas as amostras de fezes colhidas em aves com diarréia, o AvRV foi detectado em 37,8\% (14/37) e o ARV em 13,5\% (5/37) da amostragem analisada. Em fezes com aspectos normais (controle) obtidas de aves clinicamente sadias, o AvRV foi identificado em apenas 1,5\% (4/274) e o ARV não foi detectado. O ácido nucléico do PBV foi detectado com maior frequiência em fezes pastosas colhidas de aves com duas a sete semanas de vida. O AvRV apresentou grande variabilidade eletroforética dos segmentos de dsRNA, tendo sido identificados nove eletroferotipos distintos. Não foram observadas variações no perfil genômico nas amostras de ARV e também de PBV.

Palavras-chave: Rotavírus aviário, reovírus aviário, picobirnavírus aviário, frango de corte, diarréia, EGPA.

\section{REFERENCES}

1. Alfieri, A.F.; Alfieri, A.A.; Resende J.S.; Resende, M. A new bisegmented double stranded RNA virus in avian feces. Arq. Bras. Med. Vet. Zootec., 40:437-440, 1988.

2. Alfieri, A.F.; Alfieri A.A.; Resende, J.S.; Resende, M. Atypical rotavirus infections among broiler chickens in Brazil. Arq. Bras. Med. Vet. Zootec., 41:81-82, 1989a.

3. Alfieri, A.F.; Alfieri, A.A.; Resende, M.; Resende, J.S. Detection and propagation of avian enteric reovirus in chicken. Arq. Bras. Med. Vet. Zootec., 41:493-501, 1989b.

4. Alfieri, A.A.; Alfieri, A.F.; Freitas, J.C.; Silva, C.A.; Freire, R.L.; Barros, A.R.; Barreiros, M.A.B.; Müller, E.E. Ocorrência de Escherichia coli, rotavírus, picobirnavírus e Cryptosporidium parvum em um foco de diarréia do pós-desmame em suínos. Semina: Ci. Agrárias, 15:5-7, 1994.

5. Andral, B.; Toquin, D.; L'haridon, R.; Jestin A.; Metz, M. H.; Rose, R. Les diarrhées du dindonneau: un bilan des recherches virales effectuées (Rotavirus, reovirus, Adenovirus, Pseudopicornavirus). Avian Path., 14:147-162, 1985.

6. Boom R.; Sol, C.J.A.; Salimans, M.M.M.; Jansen, C.L.; Ertheimvan Dillen, P.M.E.; Noordaa-Van Der, J. Rapid and simple method for purification of nucleic acids. J. Clin. Microbiol., 28:495-503, 1990.

7. Chandra, R. Picobirnavirus, a novel group of undescribed viruses of mammals and birds: a minireview. Acta Virol., 41:59-62, 1997.

8. Decaesstecker, M.; Charlier, G.; Meulemans, G. Epidemiological study of enteric viruses in broiler chickens: Comparison of tissue culture and direct electron microscopy. Avian Path., 17:477-486, 1988.

9. Desselberger, U.; Mccrae, M.A. The rotavirus genome. Curr. Top. Microbiol. Immunol., 185:31-66, 1994.

10. Dolan, K.T.; Twist, E.M.; Horton-Slight, P.; Forrer, C.; Bell Jr, C.M.; Plotkin, A.S.; Clark, H.F. Epidemiology of rotavirus electropherotypes determined by a simplified diagnostic technique with RNA analysis. J. Clin. Microbiol., 21:753-758, 1985.

11. Estes, M.K.; Graham, D.Y.; Mason, B.B. Proteolytic enhancement of rotavirus infectivity: molecular mechanisms. J. Virol., 39:879$888,1981$.

12. Gomes, F.P. Curso de Estatística Experimental. Nobel, Piracicaba, São Paulo, 1990. 
13. Gough, R.E.; Alexander, D.J.; Collins, M.S.; Lister, A.S.; Cox, W.J. Routine virus isolation for detection in the diagnosis of diseases in birds. Avian Path., 17:893-907, 1988.

14. Grohmann, G.S.; Glass, R.I.; Pereira, H.G.; Monroe, S.S.; Hightower, A.W.; Weber, R.; Bryan, R.T. Enteric viruses and diarrhea in HIVinfected patients. New Eng. J. Med., 329:14-20, 1993.

15. Herring, A.J.; Inglis, N.F.; Ojeh, C.K.; Snodgrass, D.R.; Menzies, J.D. Rapid diagnosis of rotavirus infection by direct detection of viral nucleic acid in silver-stained polyacrylamide gels. J. Clin. Microbiol., 16:473-477, 1982.

16. Laemmli, V.K. Cleavage of strutural proteins during the assembly of the head of bacteriophage T4. Nature, 227:680-685, 1970.

17. Lozano, L.F.; Hammami, S.; Castro, A.E.; Osburn, B. Comparison of electron microscopy and polyacrylamide gel electrophoresis in the diagnosis of avian reovirus and rotavirus infections. Avian Dis., 36:183-188, 1992

18. Mcferran, J.B.; Mcnulty, M.S.; Mccracken, R.M.; Greene, J. (1983). Enteritis and associated problems. In: Hungerford, T.G. (Ed.). Disease Prevention and Control in Poultry Production, Sydney, University Press, pp 129-138.

19. Mcnulty, M.S.; Curran, W.L.; Todd, D.; Mcferran, J.B. Detection of viruses in avian faeces by direct electron microscopy. Avian Path., 8:239-247, 1979 .

20. Mcnulty, M.S.; Allan, G.M.; Mccracken, R.M. Experimental infection of chickens with rotaviruses: clinical and virological findings. Avian Path., 12:45-54, 1983.
21. Mcnulty, M.S.; Allan, G.M.; Todd, D.; Mcferran, J.B.; Mccracken, R.M. Epidemiology of rotavirus infection in broiler chickens: recognition of four serogroups. Arch. Virol., 81:113-121, 1984.

22. Pereira, H.G.; Azeredo, R.S.; Leite, J.P.G.; Barth, O.M.; Sutmoller, F.; Farias De Vidal, M.N.P. Comparison of polyacrylamide gel electrophoresis (PAGE), immunoelectron microscopy (IME) and enzyme immunoassay (EIA) for the rapid diagnosis of rotavirus infection in children. Mem. Inst. Oswaldo Cruz, 78:483-490, 1983.

23. Pereira, H.G.; Fialho, A.M.; Flewett, T.H.; Teixeira, J.M.; Andrade, Z.P. Novel viruses in human faeces. Lancet, 2:103-104, 1988.

24. Theil, K.W.; Mccloskey, C.M.; Saif, L.J.; Redman, D.R.; Bohl, E.H., Hancock, D.D.; Kohler, E.M.; Moorhead, P.D. Rapid simple method of preparing rotaviral double-stranded ribonucleic acid for analysis by polyacrylamide gel electrophoresis. J. Clin. Microbiol., 14:273280, 1981

25. Theil, K.W.; Reynolds, D.L.; Saif, Y.M. Comparison of immune electron microscopy and genome electropherotyping techniques for detection of turkey rotaviruses and rotavirus-like viruses in intestinal contents. J. Clin. Microbiol., 23:695-699, 1986

26. Todd, D.; Mcnulty, M.S. Electrophoretic variation of avian rotavirus RNA in polyacrylamide gels. Avian Path., 15:149-159, 1986.

27. White, D.O.; Fenner, F.J. Reoviridae. In: Medical Virology, 4 ed. San Diego, Academic Press, p.522-530, 1994.

28. Yason, C.V.; Summers, B.A.; Schat, K.A. Pathogenesis of rotavirus infection in various age groups of chickens and turkeys: Pathology. Am. J. Vet. Res., 48:927-938, 1987. 